\title{
The Importance of Deep Learning on Constructivism Approach
}

\author{
Sondang Aida Silalahi ${ }^{1}$, Andri Zainal ${ }^{1}$, Gaffar Hafiz Sagala ${ }^{1, *}$ \\ ${ }^{I}$ Faculty of Economics, Universitas Negeri Medan \\ *Corresponding author. Email: hafizsagala@unimed.ac.id
}

\begin{abstract}
This study aims to theoretically review the characteristics of the deep learning approach and its relation to the constructivism approach in higher education. This paper is a literature study that discusses the relevance of social constructivism theory as the theoretical basis of the learning approach practiced by lecturers and the deep learning approach as a learning orientation practiced by students. In this article, the authors believe that the learning process can rely on instructional design and student commitment in achieving valuable knowledge and skills. Because the people who are prepared to compete as superior human resources are students themselves, this study provides a theoretical view that can enrich the repertoire of knowledge in higher education learning and learning literature in higher education. Several practical recommendations were also submitted to be a concern by stakeholders and educators in implementing learning in higher education.
\end{abstract}

Keywords: Deep Learning, Constructivism, Social Learning, IQF

\section{INTRODUCTION}

In 2013, the government of the Republic of Indonesia updated the national education framework by issuing Presidential Regulation no. 8 of 2012 concerning the Indonesian National Qualifications Framework (IQF) [1], which was followed by the Minister of Education and Culture Regulation no. 73 of 2013 concerning the application of the Indonesian National Qualifications Framework (IQF) [2]. The qualification levels are set to build complex attitudes, knowledge, and skills in responding to today's increasingly competitive 21 st-century competency needs. Therefore, undergraduate alumni are emphasized not only on cognitive mastery, but also on the management of that knowledge that can provide problem-solving skills and the ability to innovate and collaborate. The same thing has happened in GATS and AFTA member countries in preparing their human resources. That is, the need for a change in this competency posture has become a global need.

Based on the Regulation of the Minister of Research and Higher Education no. 44 of 2015 concerning National Standards for Higher Education [3] that been updated in the Regulation of the Minister of Education and Culture no. 3 of 2020 concerning the National Standards for Higher Education [4], the IQF which is designed within the framework of competency levels that integrates competencies in the academic fields, training, and work experience which is built on the foundation of attitudes and values, workability, mastery of knowledge, and authority and responsibility. The achievement of competencies set out in the IQF seems to be quite complex, so that it requires a complex learning approach as well. However, if viewed theoretically, the concept is in line with the constructivism approach in teaching students. Students are placed in specific scenarios so that they automatically learn concepts that are relevant to the learning objectives so that they can construct thoughts to solve actual problems or generate specific innovation ideas.

In practice, teaching students with a constructivist approach is not an easy matter and is still an interesting study to this day. Dolmans et al. [5] stated that universities have complex challenges in preparing students to have competence in problem-solving and critical thinking that is adaptive to the times. Therefore, universities need to be careful, planned, and serious in practicing their learning designs on students. In addition, universities must also ensure student involvement in learning so that students really get a meaningful learning experience. 
On the other hand, the constructivism approach demands student readiness in learning [6]. Furthermore, the constructivism approach requires students to be active in the learning process both in exploring knowledge from various literature and in discussing with colleagues to confirm and develop their knowledge. To be engaged in student-centered learning, they need to have a strong commitment. Multiple studies in teaching and learning in higher education indicate that this commitment can be proxied by the learning approach practiced by students [7-9]. Learning approaches is classified into Deep Learning and Surface Learning [7]. Various studies have shown that students who practice deep learning approaches have better academic performance and are more successful in the actual work activities because they have a strong memory in mastering knowledge during their education [8-10]. Based on these findings, the authors suspect that the success of the constructivism approach that is practiced in the IQForiented learning program in higher education depends on students' commitment to learning, represented by the learning approach they practice. Therefore, this study aims to review the characteristics of the deep learning approach and its relation to the constructivist approach in higher education theoretically. This paper is a literature study that can enrich the repertoire of knowledge on teaching and learning in higher education.

\section{SOCIAL CONSTRUCTIVISM THEORY}

Vygotsky initiated the theory of social constructivism in 1978. The idea of social constructivism is a refinement of Piaget's cognitive theory. A person basically builds his own knowledge by connecting his past knowledge with new knowledge [6]. Knowledge construction occurs when a person interacts with other people to exchange and confirm understanding so that a new knowledge consensus emerges. Vygotsky emphasizes the interaction of social, cultural-historical, and individual aspects as the key to developing proficiency in a society [11]. Therefore, the social constructivism approach emphasizes the social context of learning by viewing that knowledge is built and constructed mutually [12]. The exchange of knowledge between students will allow them to evaluate and improve their own understanding so that new and holistic knowledge will gradually be constructed. Thus, according to the theory of social constructivism, cognitive processes must be built from a constructive learning environment, society and culture so that students arrive at logical reasoning $[6,12,13]$. In this case, if Piaget is targeting the stages of cognitive mastery, constructivism is aimed at situations that allow a person to construct his own cognitive. In the social constructivism approach, students are not only required to achieve learning goals but also have to learning to learn. This approach is very suitable for forming a lifelong educational mindset.

In addition, social constructivism focuses on a learning paradigm that makes students central in the learning process so that students are parties who should be active in the learning process [14]. Social constructivism places students as learners, not as mere listeners of information in the classroom. Thus, the process of adding, mastering, and developing knowledge is based on the students' learning activities. Therefore, the way a student learns will affect his performance in mastering the material being studied.

The qualifications expected in the IQF are targeting problem-solving, decision making, collaboration, initiative, critical thinking, and analytical skills. These skills seem to be in line with the skills to be implanted in the social constructivism approach. In practice, the learning models that are often chosen to teach students with the IQF orientation are Problem-Based Learning, Project-Based Learning, and Inquiry. These approaches produce instructional designs that place students on actual problems that require students to solve them. To solve these problems, students have scientific rules that must be followed, such as arguing based on reliable data and literature, developing group discussions, building new frameworks of thought, and presenting them to other participants in the class. The learning dynamics that the learner creates, in this case, stand on the theory of social constructivism. With this instructional design, students are expected to get a complex learning experience and form their competencies as scheduled by the IQF. However, this instructional design is faced with different individual learning orientations. This learning orientation is represented by the learning approach applied by students in achieving learning objectives.

\section{DEEP LEARNING AND CONSTRUCTIVISM APPROACH}

The learning approach is a different aspect from the learning approach. If the learning approach is an approach used by teachers to teach students, the learning approach is an approach used by students to engage in learning activities. The learning approach is the behavior or style individuals use in learning to manifest their perceptions in interacting and processing information [15]. In learning research in higher education, two approaches are hotly discussed: 
the deep learning approach and the surface learning approach. These two learning approaches are problematic for higher education practitioners in teaching students.

Students with a deep learning approach tend to enjoy the learning process by actively constructing their understanding through the process of reading literature, integrating knowledge with personal experience, and connecting various facts to conclude [15]. Furthermore, students who practice the deep learning approach generally have intrinsic motivation in themselves, so they view learning as a personal need to fulfill their curiosity [8,9]. Therefore, students with a deep learning approach are more concerned with a thorough understanding of the material given and will always try to analyze the meaning of what they learn holistically [16]. In contrast, students with the Surface learning approaches tend to focus on memorizing or carrying out the learning process simply because of the demands of the task and the existence of coercion from outside themselves [8, 15]. As a result, they learn a concept to avoid failure in their learning activities instead of understanding the idea seriously and mastering it whenever needed for actual needs in real life [17]. Thus, students with a surface learning approach tend to rely on extrinsic motivation to trigger their learning activities [9].

Based on this dichotomy, the deep learning approach is considered more suitable for learning designed with a constructivist approach. Because, in the social constructivism approach, students are required to be actively involved in learning programs. Because the social constructivism approach relies on students themselves in the learning process while the teacher acts as a facilitator. In addition, the competencies expected in the IQF are indeed critical skills rather than merely mastering knowledge or cognitive aspects. So the practice of deep learning plays a key role for students to get a meaningful learning experience. With the deep learning approach, students not only seek to know the teaching material and fully understand the concept by connecting different aspects of information to each other and then connecting it with their existing knowledge and experience [9]. Furthermore, students with a deep learning approach will have long-term memory related to mastery of knowledge due to the learning process. The dynamics of learning that he faces and enjoys will be embedded in him so that problem solving, collaboration, critical thinking, and mature decisionmaking skills are formed as required by IQF.

Thus, it can be understood that the deep learning approach is more suitable for the dynamics of learning constructivism and competencies demanded by the IQF because the deep learning approach emphasizes understanding the material in depth from a learning subject. The understanding in question is not just the result of memorizing but, more than that, the development of analysis, connections with existing knowledge, and discussions with colleagues. In addition, the learning process is carried out based on his personal curiosity or intrinsic motivation.

\section{CONCLUSION}

This article aims to review the characteristics of the deep learning approach and its relation to the constructivism approach in higher education theoretically. This discussion is essential considering the changing posture of educational qualifications in Indonesia, known as IQF. Besides, university alumni must have increasingly competitive skills, especially in analytical skills, problem-solving, critical thinking, collaboration, and decision making. Thus, competency qualification in the IQF in fact, requires a complex learning program. From this article's point of view, the complexity of the necessary learning program is facilitated in a constructivist learning approach based on social constructivism theory [6].

Interestingly, the success of learning cannot depend on the learning program alone. As individuals who will be taught these skills, students themselves should actually be the central actor in the learning process. Therefore, student learning orientation becomes a key instrument in the practice of constructivism learning. In addition, students should have and practice a deep learning approach to get meaning from the learning process they do. Deep learning provides students not only mastery of knowledge (cognitive) but also critical skills (psychomotor and affective) that are increasingly demanding, as described previously.

This paper is a literature study that can enrich the repertoire of knowledge on teaching and learning in higher education. Universities and educators should pay more attention to enlightening students regarding the urgency of learning activities themselves. The enlightenment is directed at building individual awareness to initiate them to practice the deep learning approach. This step is crucial to ensure the implementation of the IQF mandate and achieve a competitive advantage for human resources in Indonesia. 


\section{AUTHORS' CONTRIBUTIONS}

1. Sondang Aida Silalahi: designing conceptual Framework, writing the manuscript, collecting the literature.

2. Andri Zainal: designing conceptual Framework, writing the manuscript, proofread the manuscript.

3. Gaffar Hafiz Sagala: designing conceptual Framework, writing the manuscript, collecting the literature, translating.

\section{ACKNOWLEDGMENTS}

This manuscript was funded by Universitas Negeri Medan internal Grant

\section{REFERENCES}

[1] Presiden Republik Indonesia, Peraturan Presiden No 8 Tahun 2012 Tentang Kualifikasi Nasional Pendidikan Indonesia. 2012

[2] Kepemterian Pendidikan dan Kebudayaan, Peraturan Menteri Pendidikan dan Kebudayaan No. 73 tahun 2013 tentang Penerapan Kerangka Kualifikasi Nasional Indonesia Bidang Pendidikan Tinggi, 2013

[3] Kementerian Ristekdikti, Peraturan Menteri Riset, Teknologi, dan Pendidikan Tinggi No. 44 tahun 2015 tentang Standar Nasional Pendidikan Tinggi, 2015

[4] Kementerian Pendidikan dan Kebudayaan, Peraturan Menteri Pendidikan dan Kebudayaan No. 3 tahun 2020 tentang Standar Nasional Pendidikan Tinggi, 2020

[5] Dolmans, D. H. J. M., Loyens, S. M. M., Marcq, H., \& Gijbels, D., Deep and surface learning in problem-based learning: a review of the literature. Advances in Health Sciences Education, 21(5), 2016, pp 1087-1112.

[6] Vygotsky, L. S, Socio-cultural theory. Mind in Society, 6, 1978, pp 52-58.

[7] Marton, F., \& Säljö, R.,On qualitative differences in learning: I-Outcome and process. British Journal of Educational Psychology, 46(1), 1976, pp 4-11.

[8] Biggs, J. B., Student Approaches to Learning and Studying. Research Monograph. ERIC, 1987

[9] Everaert, P., Opdecam, E., \& Maussen, S., The relationship between motivation, learning approaches, academic performance and time spent. Accounting Education, 26 (1), 2017, pp 78-107.

[10] Gordon, C., \& Debus, R., Developing deep learning approaches and personal teaching efficacy within a preservice teacher education context. British Journal of Educational Psychology, 72(4), 2002, pp 483-511.

[11] Schunk, D. H., Learning theories an educational perspective sixth edition, Pearson, 2012

[12] Santrock, J., W., Psikologi Pendidikan (Edisi 2) (Terjemahan Tri Wibowo). Jakarta: Prenada Media Grup, 2007

[13] Ormrod, J. E., Human Learning. (6th ed.). United State of America: Pearson Education, Inc., 2012

[14] Han, G., dan Newell, J., Enhancing student learning in knowledge-based courses: Integrating team-based learning in mass communication theory classes. Journalism \& Mass Communication Educator, 69 (2), 2014, pp 180-196.

[15] Dejene, W., Bishaw, A., \& Dagnew, A., Preservice teachers' approaches to learning and their teaching approach preferences: Secondary teacher education program in focus. Cogent education, 5(1), 2018, p 1502396.

[16] Hamm, S., \& Robertson, I., Preferences for deepsurface learning: A vocational education case study using a multimedia assessment activity. Australasian Journal of Educational Technology, 26 (7), 2010

[17] Beattie IV, V., Collins, B., \& McInnes, B., Deep and surface learning: a simple or simplistic dichotomy? Accounting Education, 6(1), 1997, pp 1-12. 